Journal of Plant Production

Journal homepage: www.jpp.mans.edu.eg

Available online at: www.jpp.journals.ekb.eg

\title{
Early Marketable Yield and Better Berry Skin Color of 'Redglobe' Grapevines Cultivar Grown under Warm Climate by Application of Sulis ${ }^{\circledR}$
}

\author{
Mohamed, A. M. A.* and Heba S. Sayed
}

Horticulture Dept., Faculty of Agric., Minia Univ., 61-519 Minia, EGYPT.

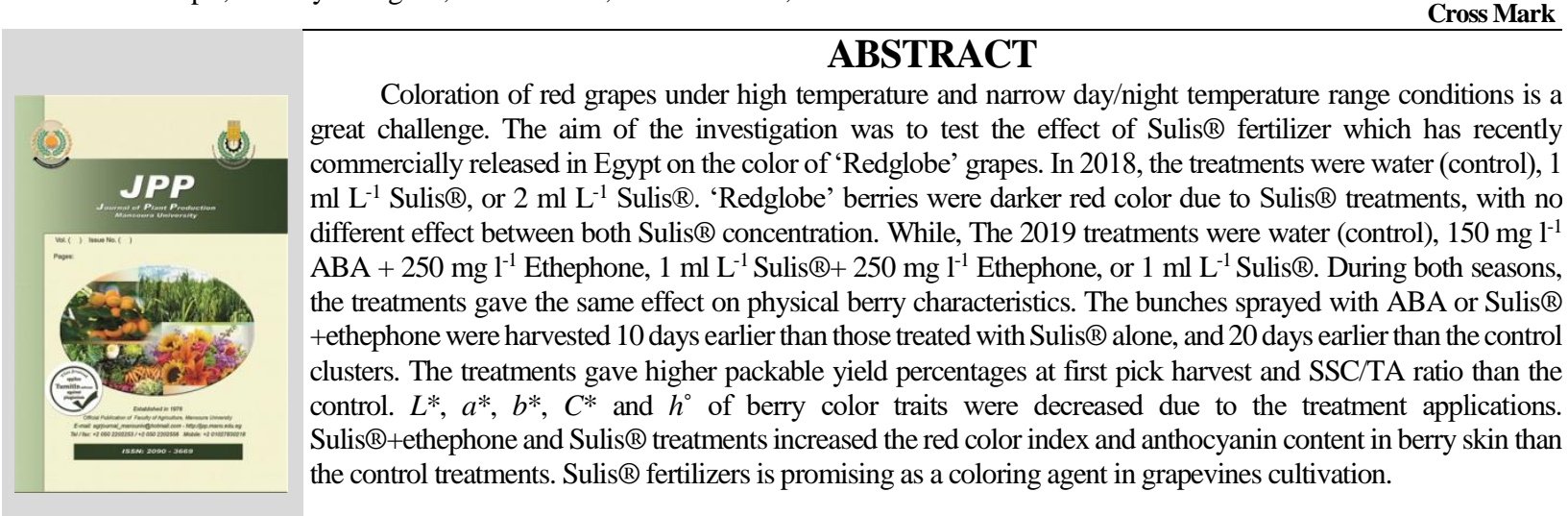

Keywords: Redglobe, Grapes color, Ethephon, Sulis $®$, Berry Skin

\section{INTRODUCTION}

Grapevines (Vitis vinifera L.) are the second major fruit crop in Egypt, after citrus. Red colored grapes are not only desired because of their attractive color, but also they have anthocyanins, which have potential effects on human health (He et al., 2010; Miao et al., 2016). Coloration of red grapes, however, is facing challenges which affect its color uniformity in within berries and cluster (Gargin and Altindisli, 2015). One of the biggest challenges is regional weather conditions, including high temperature, and narrow day/night temperature range (Spayd et al., 2002; Ferrara et al., 2013). Temperature of $30^{\circ} \mathrm{C}$ inhibits anthocyanin accumulation (Spayd et al., 2002). Lack of coloration for red tables grapes due to high temperature during harvest time has been noticed in several countries, Australia , USA, Italy, Brazil, and China (Cameron, 2001; Brar et al., 2008; Ferrara et al. 2013; Lo'ay 2017; Scavroni et al., 2018; Shahab et al., 2019; Deng et al. 2019). Under these conditions, Total soluble Solid percentage in berries might reach to commercial level (14-16 Brix) without suitable color appearance (Lurie et al., 2009). The same climate patterns are in Egypt (Omran 2011; Lo'ay 2017). Temperature rising (global warming) is likely to continue (Agrawala et al., 2004), making proper coloration of red grapes is more difficult. In Minia governorate region, where the study has taken place, has similar properties of continental climate during summer times, the weather is very hot where the temperature could reach $37.7^{\circ} \mathrm{C}$ (Attia, 1974).

'Redglobe' grapevines are widely planted due to their favorite berry characteristics; large size, firm texture, and uniform red color (Peppi et al. 2007a). Harvest of 'Redglobe' grapes in Minia governorate is earlier than the northern part of Egypt. This situation gave a great opportunity to the grower to earn better money. But, fulfillment of commercial standard coloration, under recently recorded high temperature, is a big challenge (Omran 2011).

Anthocyanins are plant pigments responsible for red color of table grapes (Roberto et al., 2013). High temperature negatively affects anthocyanin accumulation in grape berry skin (Spayd et al., 2002). Subsequently, economic values of table grapes are dramatically decreased (Peppi et al. 2006; Cantín et al., 2007).

Exogenous application of Plant growth regulators, in particular ethephone (2-Chloroethylphosphonic acid) and Abscissic (ABA), are greatly responsible to obtain higher anthocyanin content in berry skin of red grapes as suggested by Several studies (El-Kereamy et al., 2003; Mailhac and Chervin 2006; Peppi et al., 2006, 2007a,b; Cantín et al., 2007; Lauri et al., 2009; Ferrara et al., 2013;; Roberto et al., 2013; Leão et al., 2015; Yamamoto et al., 2015; Olivares et al., 2017; Scavroni et al., 2018; Deng et al., 2019). But, Application of ethephone results in berry softening which is not desirable trait (Szyjewicz et al., 1984; Peppi et al., 2007a; Peppi and Fidelibus 2008; Roberto et al., 2013). In addition, the high cost of ABA is un-acceptable practice (Peppi et al. 2006). Therefore, Alternative applications for both PGRs have been suggested, like brassinosteroids (Luan et al. 2013), methyl jasmonate (Ju et al. 2016), 2.4-epibrassinolide (Liu et al., 2016), pectin-derived oligosaccharides (Villegas et al., 2016), Sugars (Olivares et al., 2017) and cyanocobalmin (Lo'ay 2017). Moreover, stimulant Fertilizers which have the influence in enhancement berry coloration, were recently gaining favor like Potassium sources (Strydom 2014), Kaolin foliar fertilizer (Conde et al. 2016), and algae extract (Deng et al. 2019).

The goal of this study was to evaluate the effect of Sulis®, a recently introduced fertilizer in Egypt, on 
marketable yield at first pick, berry physical, chemical, and color characteristics, and anthocyanin content in berry skin of 'Redglobe' grapes.

\section{MATERIALS AND METHODS}

\section{Plant Material and Experimental Design}

The study was carried out on uniformed Six-years-old 'Redglobe' grapevines (Vitis vinifera L.) grafted onto 'Freedom' rootstock, in a commercial table grape vineyard located at Abu Qorqas district on the western desert road $\left(\left(27^{\circ} 57^{\prime} 32^{\prime \prime} \mathrm{N} ; 30^{\circ} 33^{\prime} 39^{\prime \prime} \mathrm{E}\right.\right.$, Minya, Egypt), typically subtropical zone. The vineyard production was annually devoted for exportation, where the soil was classified as sandy soil, drip irrigated with two drip lines, drippers were $0.5 \mathrm{~m}$ apart with volume of $41 / \mathrm{h}$, and water EC was $500 \mathrm{ppm}$. Vines were spaced $2 \times 3 \mathrm{~m}$, trained with short cane (6 eyes) pruning on barron's supporting system. The vineyard was performed standard practices in the area, $\mathrm{GA}_{3}$ was applied at concentration of $1 \mathrm{ppm}$ for berry thinning (full bloom), and $12 \mathrm{ppm}$ for berry sizing at $6-8 \mathrm{~mm}$, cluster thinning was carried out by removing of $40 \%$ of cluster tip skeleton at berry size 2-3 $\mathrm{mm}$ and number of clusters/vine was adjusted to $30 \pm 2$ clusters. All local recommended vineyard practices were done including fertilizer additions, pest control, canopy management, and other operations.

2018 Experiment

A complete randomized block design was used with three blocks and three treatments, three grapevines were used per each replicate. The treatments were as follow: water (control), $1 \mathrm{ml} \mathrm{L}^{-1}$ Sulis®, or $2 \mathrm{ml} \mathrm{L}^{-1}$ Sulis®. All treatments were applied two times with 7 days interval, starting at the beginning of véraison (15\% of berries on at least $50 \%$ of the experimental clusters had begun to soften, Peppi et al., 2007a) at the first week of June in 2018. The treatments were directly applied to clusters with a handled sprayer until runoff, after adding Surfactant (250 $\mathrm{mg} \mathrm{L}^{-1}$, Triton B) to all sprays. Sulis ${ }^{\circledR}$ is a proprietary mixture containing Molybdenum (Mo) $50 \mathrm{~g}$ $\mathrm{L}^{-1}$ and Boron (B) $8 \mathrm{~g} \mathrm{~L}^{-1}$ (Levity Crop Science, Preston, PR3 ORY,UK) (https: //news. levitycropscience. com/ sulis/).

Only commercial acceptable bunches were harvested when soluble solids content SSC $\geq 14^{\circ}$ Brix. Five bunches from each replicates were picked to evaluate the quality parameters. The three replicates of 20 berries were randomly chosen for measuring physical, color, and chemical characteristics. The physical properties of berries (weight (g), length $(\mathrm{mm})$, and diameter $(\mathrm{mm})$, were measured (Jensen et al., 1975). The berry color was analyzed using a colorimeter (ColorTec-PCM $^{\mathrm{TM}}$, Inc. Pittsford, New York, USA) from berry equator; the values of $L^{*}$ (luminosity), $a^{*}$, and $b^{*}$ were obtained by direct detection, all berries were washed by clean cotton before testing. The values of $C^{*}$ (chroma) and $h^{\circ}$ (hue angle) were calculated; $C^{*}=\left[a^{*} 2+b^{*} 2\right]^{1 / 2}$, and $h^{\circ}=\operatorname{arc}$ tangent $(b * / a *)$. Then, the color index of red grapes (CIRG) was determined according to a formula: $\mathrm{CIRG}=[(180$ $\left.\left.h^{\sigma}\right) /\left(L^{*}+C^{*}\right)\right]$ (Carreño et al., 1995).

\section{Experiment}

According to the 2018 results, the lower concentration of Sulis ${ }^{\circledR}\left(1 \mathrm{ml} \mathrm{L}^{-1}\right)$ was used for further investigation. A complete randomized blocks design was used with four blocks and four treatments, five grapevines were used per each replicate. The 2019 experiment was conducted in the same vineyard, and consisted four treatments; water (control), $150 \mathrm{mg} \mathrm{l}^{-1} \mathrm{ABA}+250 \mathrm{mg} \mathrm{l}^{-1}$ Ethephone (the recommended farm application ), $1 \mathrm{ml} \mathrm{L}^{-1}$ Sulis ${ }^{\circledR}+250 \mathrm{mg} \mathrm{l}^{-1}$ Ethephone, or $1 \mathrm{ml} \mathrm{L}^{-1}$ Sulis®. the treatments were applied as the same way done in 2018 .

ABA source was ProTon ${ }^{\circledR}\left(10 \mathrm{~g} \mathrm{~L}^{-1} \mathrm{~S}-\mathrm{ABA}\right.$, Valent BioSciences Corporation, Libertyville, IL, USA). Ethephone was from Ethrel ${ }^{\circledR}\left(480 \mathrm{~g} \mathrm{~L}^{-1}\right.$ Ethephone, Bayer Crop Science, Research Triangle Park, NC).

All characteristics detected in 2018, were measured in 2019 in the same way. The yield/vine, cluster number, and cluster weight were recorded. Marketable yield percentages at first pick were calculated according [(yield $(\mathrm{kg})$ per vine at first harvest time divided to total yield (kg) per vine, and then multiplied by 100], Marketable yield was characterized with commercial standard SSC \% > $14 \%$ and acceptable skin color (Berry size is not changed since the berry SSC \% reached the commercial standard level). For chemical properties of berries testing, the juice of 10 berries were extracted by hand with cheesecloth. Soluble solids contents (SSC) was measured and expressed as ${ }^{\circ}$ Brix, using a digital table refractmeter, titratable acidity (TA) was determined by titration with $0.13 \mathrm{~N} \mathrm{NaOH}$, using $5 \mathrm{ml}$ of diluted juice and expressed as $\mathrm{g}$ tartaric acid $100 \mathrm{~mL}^{-1}$ juice. Then, the relationship between SSC and TA ratio was calculated. For measuring total anthocyanin, 5 berries from each cluster randomly selected, $10 \mathrm{~mm}$-diameter skin disk from each berry was removed carefully without any pulp. The samples were rinsed with tap water, then with deionised water. The skin disks were dried with paper towels. The samples were incubated with $99 \%$ methanol [10\% (v/w) skin fresh weight $(\mathrm{FW})]$ and extracted in the dark at room temperature for $48 \mathrm{~h}$. After removing the samples from dark, they were mixed for 5 $\mathrm{s}$, then a $2 \mathrm{ml}$ aliquot was acidified with $1 \%(\mathrm{v} / \mathrm{v}) \mathrm{HCl}$ to adjust the $\mathrm{pH}$ to 1.5 for maximum anthocyanin absorption (Peppi et al. 2006). The sample absorption was measured at $520 \mathrm{~nm}$ using a spectrophotometer (Perkin-Elmer, LAMBDA 2). Total anthocyanins were expressed as $\mathrm{mg} \mathrm{cm}^{-}$ 2 of skin (Peppi 2004).

Statistical analysis: the differences between the treatment means in 2018 and 2019 seasons were evaluated by the analysis of variance (ANOVA), and significant differences were subjected to Duncan's multiple range test at $\mathrm{P}<0.05$ ((according to Mead et al., 1993). All the data analysis was performed with MSTATC software.

\section{RESULTS AND DISCUSSION \\ 2018 Experiment}

2018 experiment was designed to stand out the effect Sulis ${ }^{\circledR}$ on 'Redglobe' grapes quality with preliminary results. The clusters in season 2018 were harvested when SSC reached to marketable level; Sulis® treatments gave higher SSC values than the control (Data not shown). Table 1 presents two different characteristic groups of 'Redglobe' berries, physical and coloration in 2018. All berry physical characteristics including weight, length, and diameter values were not significantly differed among the treatments. Data shown in Table (1) declare that treatments of Sulis ${ }^{\circledR}$ at $1 \mathrm{ml}$ $\mathrm{L}^{-1}$ had similar effects in all chromatic parameters, comparing with treatment of Sulis ${ }^{\circledR}$ at $2 \mathrm{ml} \mathrm{L}^{-1}$. On the other hand, Sulis ${ }^{\circledR}$ treatments did significant effect in berry skin color parameters $\left(a^{*}, b^{*}, L^{*}, C^{*}, h^{\circ}\right.$ and CIRD) compared with 
control treatment (Table 1$)$. The values of $\mathrm{C}^{*}$ and $\mathrm{h}^{\circ}$ of berry color parameters (7.77 and 18.77 , respectively) were lower than clusters treated with Sulis ${ }^{\circledR} 1 \mathrm{ml} \mathrm{L}^{-}$than those treated with control (8.39 and 21.80, respectively). Thereby, the color of cluster berries that received Sulis $® 1 \mathrm{ml} \mathrm{L}^{-1}$ application were darker red-color than those received the control treatment. Sulis® $1 \mathrm{ml} \mathrm{L}^{-1}$ application increased CIRG value
(3.81) with remarkable effect than the CIRG value (3.42) obtained from control treatment. These results confirmed that the treated grapes with Sulis ${ }^{\circledR}$ were darker red-color than untreated. The same treatments were applied to ten-year-old own-rooted 'Redglobe' grapevines grown in clay loam soil in 2018 season. The results had the same trends as data represented in this article (data not shown).

Table 1. The effect of Sulis® concentrations on berry physical and color characteristics of 'Redglobe' grapes in 2018.

\begin{tabular}{|c|c|c|c|c|c|c|c|c|c|}
\hline \multirow[b]{2}{*}{ Treatments } & \multicolumn{3}{|c|}{ Berry physical } & \multicolumn{6}{|c|}{ Berry color } \\
\hline & $\begin{array}{c}\text { weight } \\
\text { (g) }\end{array}$ & length (mm) & $\begin{array}{c}\text { diameter } \\
(\mathbf{m m})\end{array}$ & $\mathbf{a}^{*}$ & $\mathbf{b}^{*}$ & $\mathbf{L}^{*}$ & $\mathbf{C}^{*}$ & $\mathbf{h}^{\mathbf{o}}$ & CIRG \\
\hline Control & $12.1^{\mathrm{a}}$ & $2.7^{\mathrm{a}}$ & $2.5^{\mathrm{a}}$ & $7.8^{\mathrm{a}}$ & $3.1^{\mathrm{a}}$ & $37.85^{\mathrm{a}}$ & $8.40^{\mathrm{a}}$ & $21.82^{a}$ & $3.42^{\mathrm{b}}$ \\
\hline Sulis® $1 \mathrm{ml} \mathrm{L}^{-1}$ & $11.9^{\mathrm{a}}$ & $2.7^{\mathrm{a}}$ & $2.5^{\mathrm{a}}$ & $7.3^{\mathrm{b}}$ & $2.5^{\mathrm{b}}$ & $34.60^{\mathrm{b}}$ & $7.73^{b}$ & $18.78^{b}$ & $3.81^{\mathrm{a}}$ \\
\hline Sulis® $2 \mathrm{ml} \mathrm{L}^{-1}$ & $12.2^{\mathrm{a}}$ & $2.6^{\mathrm{a}}$ & $2.4^{\mathrm{a}}$ & $7.2^{\mathrm{b}}$ & $2.4^{\mathrm{b}}$ & $34.70^{\mathrm{b}}$ & $7.60^{\mathrm{b}}$ & $18.27^{b}$ & $3.82^{\mathrm{a}}$ \\
\hline
\end{tabular}

Means followed by different higher-case letters within a column are significantly different according to Duncan's multiple range test $(P \leq 0.05)$.

Table 2. Effect of the treatments on the yield properties and berry physical characteristics of 'Redglobe' grapes in 2019.

\begin{tabular}{lccccccc}
\hline & yield/ & \multicolumn{3}{c}{ Yield properties } & \multicolumn{2}{c}{ Berry physical characteristics } \\
Treatments & $\begin{array}{c}\text { vine } \\
\text { (kg) }\end{array}$ & $\begin{array}{c}\text { cluster } \\
\text { weight } \\
(\mathbf{g})\end{array}$ & $\begin{array}{c}\text { marketable } \\
\text { yield at first } \\
\text { pick(Kg) }\end{array}$ & $\begin{array}{c}\text { marketable } \\
\text { Yield at first } \\
\text { pick\% }\end{array}$ & $\begin{array}{c}\text { weight } \\
\text { (g) }\end{array}$ & $\begin{array}{c}\text { length } \\
\text { cm }\end{array}$ & $\begin{array}{c}\text { diameter } \\
\text { cm }\end{array}$ \\
\hline Control & $30.50^{\mathrm{a}}$ & $984^{\mathrm{a}}$ & $3.1^{\mathrm{c}}$ & $10^{\mathrm{c}}$ & $12.3^{\mathrm{a}}$ & $2.9^{\mathrm{a}}$ & $2.7^{\mathrm{a}}$ \\
ABA+ethephone & $30.60^{\mathrm{a}}$ & $1020^{\mathrm{a}}$ & $7.4^{\mathrm{a}}$ & $24^{\mathrm{a}}$ & $12.0^{\mathrm{a}}$ & $2.8^{\mathrm{a}}$ & $2.6^{\mathrm{a}}$ \\
Sulis®+ethephone & $30.89^{\mathrm{a}}$ & $936^{\mathrm{a}}$ & $6.8^{\mathrm{a}}$ & $22^{\mathrm{a}}$ & $11.7^{\mathrm{a}}$ & $2.6^{\mathrm{a}}$ & $2.5^{\mathrm{a}}$ \\
Sulis® & $29.52^{\mathrm{a}}$ & $984^{\mathrm{a}}$ & $4.8^{\mathrm{b}}$ & $16^{\mathrm{b}}$ & $12.0^{\mathrm{a}}$ & $2.8^{\mathrm{a}}$ & $2.6^{\mathrm{a}}$ \\
\hline
\end{tabular}

Means followed by different higher-case letters within a column are significantly different according to Duncan's multiple range test $(P \leq 0.05)$.

\section{Experiment}

The clusters were sprayed with a mixture of ABA or Sulis ${ }^{\circledR}+$ ethephone reached to the marketable quality at 8 of June 2019. The mixture treatments clusters were harvested 10 days earlier than those treated with Sulis ${ }^{\circledR}$ alone (18 of June 2019), and 20 days earlier than the control clusters (28 of June 2019). It means that clusters sprayed with Sulis ${ }^{\circledR} 1 \mathrm{ml} \mathrm{L}^{-1}$ were harvested in 10 days earlier than those sprayed with the check treatment. Data showen in Table (2) declared that all treatments gave similar results in yield/vine and individual cluster weight in comparison with the control.

Marketable yield was weighted at the first pick time for each treatment and later after finishing the harvest, then the percentages of marketable yield at first harvest time was calculated. All treatments showed significant differences in percentages of packable yield except between $\mathrm{ABA}+$ ethephone and Sulis ${ }^{\circledR}+$ ethephone treatments. The highest percentage of packable clusters at first pick was $24 \%(7.4 \mathrm{~kg})$ obtained from grapevines received $\mathrm{ABA}+\mathrm{ethephone}$, followed by $22 \%(6.8 \mathrm{~kg})$, and $16 \%(4.8 \mathrm{~kg})$ obtained from those received Sulis ${ }^{\circ}+$ ethephone and Sulis $\AA$, respectively. While the lowest percentage of packable clusters was $10 \%$ $(3.1 \mathrm{~kg})$ for grapevines treated with control.
On the other hand, Treatments did not significantly affect the berry physical characteristic, including berry weight, berry length, and berry diameters in 2019, although slightly decreases in their values comparing with the control (Table 2).

Table 3. Effect of the treatments on berry chemical characteristics of 'Redglobe' grapes in 2019.

\begin{tabular}{llcc}
\hline Treatments & SSC & TA & SSC/TA \\
\hline Control & $15.5^{\mathrm{c}}$ & $0.559^{\mathrm{a}}$ & $27.73^{\mathrm{c}}$ \\
ABA+ethephone & $17.0^{\mathrm{a}}$ & $0.437^{\mathrm{c}}$ & $38.90^{\mathrm{a}}$ \\
Sulis®+ethephone & $16.8^{\mathrm{a}}$ & $0.445^{\mathrm{c}}$ & $37.75^{\mathrm{a}}$ \\
Sulis® & $15.9^{\mathrm{b}}$ & $0.516^{\mathrm{b}}$ & $30.81^{\mathrm{b}}$ \\
\hline
\end{tabular}

Means followed by different higher-case letters within a column are significantly different according to Duncan's multiple range test $(P \leq \mathbf{0 . 0 5})$ SSC, TA, and SSC/TA were affected by treatments as shown in Table 3. The highest values of SSC \% and SSC/TA (17.0 and 38.90), respectively, were recorded with application of ABA+ethephone, the similar effect was obtained from Sulis $®+$ thephone application. Sulis ${ }^{\circledR}$ spray had a significantly higher effect on SSC and SSC/TA than the control. On the other hand, the highest TA values were obtained from control treatment, followed in order by Sulis ${ }^{\circledR}$, Sulis ${ }^{\circledR}+$ ethephone, and ABA+ethephone (Table 3).

Table 4. Effect of the treatments on berry color characteristics and Anthocyanins content of "Redglobe" grapes in 2019.

\begin{tabular}{|c|c|c|c|c|c|c|c|}
\hline \multirow[b]{2}{*}{ Treatments } & \multicolumn{7}{|c|}{ Berry color characteristics } \\
\hline & $L^{*}$ & $a^{*}$ & $b^{*}$ & $C^{*}$ & $\boldsymbol{h}^{\circ}$ & CIRG & $\begin{array}{l}\text { Anthocyanins } \\
\text { mg cm² skin }\end{array}$ \\
\hline Control & $37.93^{\mathrm{a}}$ & $8.2^{\mathrm{a}}$ & $3.2^{\mathrm{a}}$ & $8.81^{\mathrm{a}}$ & $21.33^{\mathrm{a}}$ & $3.40^{c}$ & $0.0075^{\mathrm{b}}$ \\
\hline ABA+ethephone & $35.44^{\mathrm{c}}$ & $6.7^{\mathrm{c}}$ & $1.9^{\mathrm{c}}$ & $6.97^{\mathrm{c}}$ & $15.87^{\mathrm{c}}$ & $3.87^{\mathrm{a}}$ & $0.0186^{\mathrm{a}}$ \\
\hline Sulis®+ethephone & $34.95^{\mathrm{c}}$ & $6.9^{c}$ & $2.0^{\mathrm{c}}$ & $7.18^{c}$ & $15.82^{\mathrm{c}}$ & $3.90^{\mathrm{a}}$ & $0.0172^{\mathrm{a}}$ \\
\hline Sulis@ & $36.06^{\mathrm{b}}$ & $7.3^{b}$ & $2.3^{\mathrm{b}}$ & $7.68^{b}$ & $17.49^{\mathrm{b}}$ & $3.72^{b}$ & $0.0113^{b}$ \\
\hline
\end{tabular}

Means followed by different higher-case letters within a column are significantly different according to Duncan's multiple range test $(P \leq 0.05)$

$L^{*}, a^{*}, b^{*}, C^{*}$, and $h^{\circ}$ of berry color traits were $\mathrm{ABA}+$ ethephone and Sulis ${ }^{\circledR}+$ ethephone showed the same significantly decreased due to the treatment applications, effect on those traits, and had lower values than those of compared with those recorded from control berries as Sulis® and control treated berries. Sulis ${ }^{\circledR}$ treated berries had represented in table 4. Both mixture treatments significant less lightness $\left(L^{*}\right)$; means darker, and less hue 


\section{Mohamed, A. M. A. and Heba S. Sayed}

angle $h^{\circ}$ (more redness), than control treated berries as found in 2018 season. The color index of red grapes (CIRG) is used to show the effect of treatments the color of full ripe grapes. There were significant differences among the treatments in CIRG, confirming that $\mathrm{ABA}$ or Sulis ${ }^{\circledR}$ +ethephone resulted in larger values (3.87 and 3.0, respectively) than Sulis ${ }^{\circledR}$ (3.72) and control (3.40). Sulis® application increased CIRD values significantly than the control. These results (Table 4) declared that berries treated with $\mathrm{ABA}+$ ethephone and Sulis®+ethephone were darker red-color than other treatments. While, Sulis $®$ treatment resulted in darker redcolor berries than the control.

The data in table 4 showed the effect of the treatments on berries anthocyanin contents. Grapes treated with ABA or Sulis ${ }^{\circledR}+$ +ethephone had the highest values of anthocyanins content ( 0.0186 and $0.172 \mathrm{mg} \mathrm{cm}^{2}$ skin, respectively), with no significant effects between both treatments. The lowest value of total anthcyanins $\left(0.0075 \mathrm{mg} \mathrm{cm}{ }^{2}\right.$ skin) was obtained from bunches treated in control vines, surpassed significantly with those treated with Sulis ${ }^{\circledR}\left(0.0113 \mathrm{mg} \mathrm{cm}^{2}\right.$ skin $)$.

\section{Discussion}

Sulis ${ }^{\circledR}$ has been recently introduced in Egypt as a fertilizer which enhances fruit colors with registration number of 8743 in Nov., 2017, via United Group for Agricultural Import, Export, Trading and development Co. (Tokh ElKhil, 61-725 Minia, Egypt).

The trial in 2018 was a pre-experiment to stand out the effects of Sulis ${ }^{\circledR}$ on 'Redglobe' grape berries. Sulis ${ }^{\circledR}$ application did not affect berry physical parameters studied in 2018 season. On the other hand, Sulis ${ }^{\circledR}$ application resulted in darker red-color in berries than control. In all investigated traits in 2018, there were no significant differences between both concentration of Sulis® at $1 \mathrm{ml} \mathrm{L}^{-1}$ or $2 \mathrm{ml} \mathrm{L}^{-1}$, thereby, concentration of Sulis $\AA^{\text {at }} 1 \mathrm{ml} \mathrm{L}^{-1}$ was selected for a further study in 2019.

The special formulation in Sulis ${ }^{(}(5 \% \mathrm{Mo}, 0.8 \% \mathrm{~B})$ helps fruit build better levels of colour and brix to allow earlier picking (https://news.levitycropscience.com/sulis/). Effect of Mo and B studies was previously focused on their effects on berry sitting and yield of grapevines, and they were applied before véraison (Williams et al., 2004; Longbottom et al., 2010; Masi and Bosli 2011; Batukaev et al., 2016; Ekbic et al., 2018). Sulis ${ }^{\circledR}$ activates the plant's natural process of maturity, whilst ensuring these key nutrients in the process are available. It promotes the processes of maturation that are normally triggered by the hormone $\mathrm{ABA}$ (https://news.levitycropscience.com/sulis/). Thereby, Sulis ${ }^{\circledR}$ increases the effects of endogenous S-ABA and acts as a plant growth regulator (https://news.levitycropscience.com/sulis/). The hormone ABA might be responsible to anthocyanin accumulation in grape berry skin (Lee et al., 1979; Tomana et al., 1979).

In 2019, the experiment design contained four treatments, of which S-ABA+ethephone treatment is the vineyard recommended application. Since Sulis $®$ encourages the effects of endogenous ABA, one of the treatments designed from Sulis $®+e t h e p h o n e$ in order to compare its effect with the vineyard recommended application.

Yield, cluster weight, berry physical (weight, length, and diameter), in 2019 season, were not significantly different between the PGRs treatments and control. Yield and cluster weight is mainly depending on berry weight. The results of berry weight were in similar to noticed by Peppi et al. (2007a), Omran (2011) and Deng et al. (2019) for 'Redglobe', Peppi et al. (2007b), Peppi and Fidelibus (2008), Lurie et al. (2009) and Ferrara et at. (2013) for 'Crimson Seedless' grapes, and Kishino and Roberto (2007) for 'Rubi' grape, when they applied PGRs. These results, however, were in disagreement with those reported by Peppi et al. 2006 in 'Flame Seedless', Koyama et al. (2014) for 'Isabel' and Neto et al. (2017) for 'Rubi'. These results might be related to ABA may regulate berry composition rather than fruit growth (Düring et al., 1978; Kataoka et al. 1982; Matsushima et al., 1989).

Starting harvest, however, was earlier with Spraying PGRs than control, and increased the ratio of marketable yield at the first harvest date. In Egypt, the exportation for Redglobe grapes is so narrow, The applications which result in an earlier harvesting with a bigger amount of marketable yield increase the outcomes for the growers who dedicated their yield for exportation. There were similar results detected from ABA+ethephone or Sulis $®+$ ethephone. These results were similar to obtained from application of PGRs (Düring et al., 1978; Lee et al. 1997; Peppi et al.. 2006, 2007b; Cantín et al. 2007; Lauri et al 2009; Ferrara et al., 2013, 2015 ).

The marketable of SSC and SSC/TA ratio were accomplished earlier in vines treated with Sulis ${ }^{\circledR}, \mathrm{ABA}$ and ethephone. SSC and SSC/TA ratio were higher due to the application of PGRs. TA, however, was less in treated vines than control. The lowest results were obtained from application ABA+ethephone and Sulis®+ethephone. Increasing SSC and SSC/TA and reducing TA of table grapes due to application of ethephone plus ABA were previously reported by Peppi et al. (2006). Higher sugar accumulation for 'Cabernet Sauvignon' grapes with application of ethephon, due to released ethylene leads to the expression of genes encoding sucrose transporters, resulting in higher sucrose translocation from biosynthesis sites to the berry vacuole, in which sucrose is enzymatically converted into glucose and fructose (Chevrin et al. 2006). In addition, Sulis® at $1 \mathrm{ml} \mathrm{L}^{-1}$ application was accompanied with higher level of SSC and Lower TA. These results might be due to Sulis® is responsible for increasing the endogenous $\mathrm{ABA}$ in berries. Increasing $\mathrm{ABA}$ level in berries during ripening stages was recorded by Coobe and Hale, (1973), Coombe (1976) and Düring et al. (1978).

$L^{*}, a^{*}$, and $b^{*}$ values of PGRs treated-berries were less than the control. The conversion of these $L^{*}, a^{*}$, and $b^{*}$ to lightness, chroma, and hue showes into lower lightness and hue values and in general. Reductions of $L^{*}, C^{*}$ and $h^{\circ}$ in grape skin, due to application of ABA, ethephone or both together, were previously observed by Kim et al. (1998), Peppi et al. (2006); Lurie et al. (2009), Omran (2011), Ferrara et al. (2013), and Olivares et al. (2017) . But, Cantín et al. (2007) found that $h^{\circ}$ and $L^{*}$ values were not differed than the control when ABA or ethephone were applied. A reduction of both lightness and purity of color and the reduction of $h^{\circ}$ indicates on promotion of a more red-color development of berry skin (Peppi et al., 2007a).

Color index for classifying red grape berries (CIRG) were confidential applied (Carreño et al., 1995; FernándezLopez et al., 1998). CIRG values in this trail were increased with the treatments, weather the treatment included Sulis ${ }^{\circledR}$ 
alone or with ethephone, or ABA with ethephone. The same results were obtained when $\mathrm{ABA}$ was sprayed (Kim et al., 1998; Omran 2011; Olivares et al., 2017). On the other hand, ABA application did not affect CIRG as reported by Cantín et al. (2007); Roberto et al. (2013). Any way the berries considered as pink-colores between 2 and 4 CIRG (Carreño et al. 1995), all previously reported values of CIRG for 'Redglobe' grapes were within this rang (Peppi et al., 2007a; Omran 2011; Mekawy and Ahmed 2018; Deng et al., 2019).

Anthocyanin is the most important natural colorants in grapes (He et al. 2010). Skin anthocyanin concentrations had a pronounced effect on $L^{*}$ and $h^{\circ}$ of the berries, especially at low pigment concentration. Application of ethephone plus ABA or Sulis ${ }^{\circledR}$ inceased the red-color in berries, as well as anthocyanin content. It was well confirmed that ethephone increases the anthocyanin content in berries skin (Chervin et al. 2006; Peppi et al., 2006; Cantín et al, 2007; Scavroni et al. 2017). The increase of anthocyanin content in berry- treated ethephone is thought to be related to the higher ethephoneinduced endogenous ethylene production which leads to the transcription of genes encoding important enzymes from the biosynthetic pathway involving these pigments such as PAL, CHS, UDP; GST (Sudha and Ravishankar 2003; Chervin et al. 2006; Scavroni et al. 2017). Exogenous ABA improved grape coloration in respect of increasing anthocyanin content (Peppi et al., 2007a and Deng et al., 2019 on 'Redglobe'; Reberto et al., 2013 on 'Rubi'; Cantín et al. 2007 and Peppi et al. 2008 'Crimson Seedless'). Peppi et at., 2006 reported that Application of ABA plus ethephone resulted in darker red-color of 'Flame Seedless' grapes. This effect might be related that the exogenous $\mathrm{ABA}$ involved with the relative expressions levels of genes in the anthocyanin biosynthesis, either at particular stages or throughout the fruit ripening process (Gagné et al., 2011; Koyama et al., 2018; Deng et al., 2019). Sulis® fertilizer with its special formulation increases the endogenous $\mathrm{ABA}$ level in berries during ripening period; this might be the same effect like exogenous application of ABA as reported by Ferrara et al. (2013) who found that the exogenous $\mathrm{ABA}$ increases the level of endogenous $\mathrm{ABA}$ level. This could explain why ABA+ethephone treatment did the same effect as Sulis®+ethephone.

Ethephone plus ABA or Sulis ${ }^{\circledR}$ had similar effects in all studied traits. Exogenous ABA application per acre costs about $500 \$$, while Sulis $®$ application per acre costs $35 \$$. It is a great difference related to the cost of exogenous $\mathrm{ABA}$ and Sulis ${ }^{\circledR}$ applications per acre.

\section{CONCLUSION}

Sulis $®$ fertilizer has recently commercially released in Egypt. Sulis ${ }^{\circledR}$ did generally significant enhancement color of 'Redglobe' grapes grown in Minia governorate which was classified a warm region, and resulted in earlier harvest date with great marketable yield at first harvest date. These effects were better when Sulis ${ }^{\circledR}$ applied along with ethephone. Further studies will be needed to understand physiological effects of Sulis®.

\section{REFERENCES}

Agrawala, S., Moehner, A., El Raey, M., Conway, D., van Aalst, M., Hagenstad, M., Smith, J. 2004. Development and climate change in Egypt: focus on coastal resources and the Nile. Environment Directorate, Environment Policy Committee, working party on global and structural policies, working party on development co-operation and environment. COM/ENV/EPOC/DCD/ DAC(2004)1/FINAL

Attia, F.A. 1974. Parameters and Characteristics of the Ground water Reservoir in Upper Egypt. Ph.D. Thesis, Faculty of Engineering, Cairo University, Egypt.

Batukaev, A., Magomadov, A., Sushkova, S., Minkina, T., and Bauer, T. 2016. Influence of boron fertilization on productivity of grape plants. 39th World Congress of Vine and Wine of the OIV// BIO Web of Conferences, $7: 1-5$

Brar, H.S., Singh, Z., Swinny, E. and Cameron, I. 2008. Girdling and grapevine leafroll associated viruses affect berry weight, colour development and accumulation of anthocyanins in 'Crimson Seedless' grapes during maturation and ripening. Plant Sci., 175:885-897.

Cameron, I. 2001. Crimson Seedless promise WA table grape boon. J. Agric., 42 (1): 24-29.

Cantín, C.M., Fidelibus, M.W. and Crisosto, C.H. 2007. Application of abscisic acid (ABA) at veraison advanced red color development and maintained postharvest quality of Crimson Seedless grapes. Postharvest Biol. Technol., 46:237-241.

Carreño, J., Martinez, A., Almela, L., and Fernandez-Lopez, J. A. 1995. Proposal of an index for objective evaluation of the colour of red table grapes. Food Res. Int., 28:373-377.

Chervin, C.,Terrier, N., Ageorges, A., Ribes, F.A., and Kuapuny, T. 2006. Influence of ethylene on sucrose accumulation in grape berry. Amer. J. Enol. Vitis., 57:511-513.

Conde, A., Pimentel, D., Neves, A., Dinis, L.T., Bernardo, S., Correia, C. M., Gerós, H., and Moutinho-Pereira, J. 2016. Kaolin foliar application has a stimulatory effect on phenylpropanoid and flavonoid pathways in grape berries. Fron. Plant Sci., 7:1-14.

Coombe, B.G. 1976. The development of fresh fruits. Ann. Rev. Plant Physiol., 27:207-227.

Coombe, B.G., and Hale, H.Z. 1973. The hormone content of ripening grape berries and the effects of growth substance treatments. Plant Physiol., 51:629-634

Deng, Q., Xia H., Lin, L., Wang, J., Yuan L., Li, K., Zhang, J., Lv X. and Liang D. 2019. SUNRED, a natural extract based biostimulant, application stimulates anthocyanin production in the skins of grape. Sci. Rep., 9:1-8.

Düring H., Alleweldt, G. and Koch, R. 1978. Studies on hormonal control of ripening of grapevines. Acta Hortic., 80:397-405.

Ekbic, H. B., Gokdemir, N., and Erdem, H. 2018. Effects of boron on yield, quality and leaf nutrients of Isabella (Vitis labrusca L.) grape cultivar. Acta Sci. Pol. Hortorum Cultus, 17 (1):149-157. 
Mohamed, A. M. A. and Heba S. Sayed

El-kereamy, A., Chervin, C., Souquet, J., Moutounet, M., Monje, M.; Nepveu, F., Mondies, H., Ford, C.M., van-Ileeswijck, R., and Routan, J. 2003. Exogenous ethylene stimulates the long-term expression of genes related to anthocyanin biosynthesis in grape berries. Physiologia Plantarum, Lund, 119:175-182.

Fernández-Lopez, J.A., Almela, L., Muñoz, J.A., Hidalgo, V. and Carreño, J. 1998. Dependence between colour and individual anthocyanin content in ripening grapes. Food Res. Int., 31:667-672.

Ferrara, G., Mazzeo, A., Matarrese, A.M.S., Pacucci, C., Pacifico, A., Gambacorta, G., Faccia, M., Trani, A., Gallo, V., Cafagna, I. and Mastrorilli, P. 2013. Application of Abscisic acid (S-ABA) to 'Crimson Seedless' grape berries in a Mediterranean climate: Effects on Color, Chemical Characteristics, metabolic profile, and S-ABA concentration. Plant Growth Regul., 32(3):491- 505.

Ferrara, G., Mazzeo, A., Matarrese, M.A.S., Pacucci, C., Punzi, R., Faccia, M., Trani, A., and Gambacorta, G. 2015. Application of abscisic acid (S-ABA) and sucrose to improve color, anthocyanin content and antioxidant activity of cv. Crimson Seedless grape berries. Aust. J. Grape Wine Res., 21:18-29.

Gagné, S., Cluzet. S., Mérillon, J.M., and Gény, L. 2011. ABA initiates anthocyanin production in grape cell cultures. J. Plant Growth Regul., 30:1-10.

Gargin, S. and Altindisli, A. 2015. Determination of phenolic compositions and quality characteristic of some local Turkish table grape varieties cultivated in Egirdir/Isparta. Bio Web of Conferences 5, 04004:115.

Han, D.H., and Lee, C.H. 2004. Effects of GA3, CPPU and ABA applications on the quality of kyoho (Vitis vinifera L. X Labrusca L.) grape. Acta Hortic., 653:193-197.

He, F., Mu L., Yan G., Liang N., Pan Q., Wang J., Reeves M. J. and Dunan C. 2010. Biosynthesis of anthocyanins and their regulation in colored grapes. Molecules 15: 9055-9091.

Jensen, F.L., Kissler, J., Peacock, W., and Leavitt, G. 1975. Effect of ethephone on color and fruit characteristics of Tokay and Emperor table grapes. Amer. J. Enol. Vitic., 26:79-81.

Jeong, S.T., Goto-Yamamoto, N., Kobayashi, S., and Esaka, M. Effects of plant hormones and shading on the accumulation of anthocyanins and the expression of anthocyanin biosynthetic genes in grape berry skin. Plant Sci. 2004, 167, 247-252.

Ju, Y. L., Liu, M., Zhao, H., Meng, J. F. and Fang, Y. L. 2016. Effect of exogenous abscisic acid and methyl jasmonate on anthocyanin composition, fatty acids, and volatile compounds of cabernet sauvignon (Vitis vinifera L.) grape berries. Molecules 1: 1-15.

Kataoka I., Sugiura, A., Utsunomiya, N. and Tomana, T. 1982. Effect of abscisic acid and defoliation on anthocyanin accumulation in Kyoho grapes (Vitis vinifera L. x V. labruscana Bailey).Vitis, 21:325-332.

Kim, S.K., Kim, J.T., Jeon, S.H., Nam, Y.S. and Kim, S.H. 1998. Effects of ethephon and ABA application on coloration, content and composition of anthocyanin in grapes (Vitis spp.). J. Kor. Soc. Hort. Sci., 39:547554.
Kishino, A.A. and Roberto, S.R. 2007. Implantação do pomar. In: Kishino, A.Y., Carvalho, S.L.C. de, Roberto, S.R. (Ed.). Viticultura tropical: o sistema de produção do Paraná. Londrina: Instituto Agronômico do Paraná, 141-169.

Koyama, R., Assis, A.M., Yamamoto, L.Y., Borges, W.F., Borges, R.S., Prudêncio, S.H. and Roberto, S.R. 2014. Exogenous abscisic acid increases the anthocyanin concentration of berry and juice from 'Isabel' grapes (Vitis labrusca L.). HortScience, 49:460-464.

Koyama, R., Roberto, S.R., de Souza, R.T., Borges, W.F.S. Anderson, M., Waterhouse, A.L., Cantu, D., Fidelibus, M.W. and Blanco-Ulate, B. Exogenous Abscisic Acid Promotes Anthocyanin Biosynthesis and Increased Expression of Flavonoid Synthesis Genes in Vitis vinifera $\times$ Vitis labrusca Table Grapes in a Subtropical Region. Front. Plant Sci. 2018, 9, 323.

Leão, P.C.S., Lima, M.A.C., Costa, J.P.D. and Trindade, D.C.G. 2015. Abscisic acid and ethephon for improving red color and quality of crimson seedless grapes grown in a tropical region. Am. J. Enol. Vitic. $66: 37-45$.

Lee, J.C.,Tomana, T., Utsonomiy N. and Kataoka, I. 1979. Physiological studies on the anthocyanin development in grape. I. Effect of fruit temperature on the anthocyanin development in Kyoho grape. J. Korean Soc. Hortic. Sci., 20:55-65.

Lee, K.S., Lee, J.C., Hwang, Y.S. and Hur, I.B. 1997. Effects of natural type (S)-(?)- abscisic acid on anthocyanin accumulation and maturity in 'Kyoho' grapes. J. Korean Soc. Hortic. Sci., 38:717-721.

Liu, Q., Xi, Z., Gao, J., Meng, Y., Lin, S. and Zhang, Z. 2016. Effects of exogenous 24-epibrassinolide to control grey mould and maintain postharvest quality of table grapes. Inter. J. Food Sci. Tech., 51:1236-1243.

Lo'ay, A.A. 2017. Improvement berry color skin profile by exogenous cyanocobalamin treatment of 'Crimson Seedless’ grapevines. Egy. J. Basic. Appl. Sci., 4:231235.

Longbottom, M.L., Dry, P.R., and Sedgley, M. 2010. Effects of sodium molybdate foliar sprays on molybdenum concentration in the vegetative and reproductive structures and on yield components of Vitis vinifera cv. Merlot. J. Grape Wine Res., 16:477-490.

Luan, L. Y., Zhang, Z. W., Xi, Z. M., Huo, S. S. and Ma, L. N. 2013. Brassinosteroids regulate anthocyanin biosynthesis in the ripening of grape berries. South Afr. J. Enol. Viti., 34 (2):196-203.

Lurie, S.T., Ovadia, R., Nissim-Levi, A., Oren-Shamir, M., Kaplunov, T., Zutahi, Y., Weksler, H. and Lichter A .2009. Abscisic acid improves colour development in 'Crimson Seedless' grapes in the vineyard and on detached berries. J. Hortic. Sci. Biotech., 84:639-644.

Mailhac, N. and Chervin, C. 2006. Ethylene and grape berry ripening. Stewart Postharvest Review, London, 2:1-5.

Masi, E. and Boselli, M. 2011. Effects on yield quality of the grapevine Sangiovese (Vitis vinifera L.). Adv. Hort. Sci., 25(1): 37-43

Matsushima, J., Hiratsuka, S., Taniguchi, N., Wada, R. and Suzaki, N. 1989. Anthocyanin accumulation and sugar content in the skin of grape cultivar'Olympia' treated with ABA.J.Jap.Soc. for Hort.Sci.,58:551555. 
Mead, R.; Currnow, R.N. and Harted, A.M. (1993): Methods in Agricultural and Experimental and Biology 2nd Ed. Hall, London, pp. 10- 44.

Mekawy, A. Y. and Ahmed, A.S.S. 2018. Effect of abscisic acid and green tea extract on fruit quality of 'Redglobe' grapevines. Middle East J. Appl. Sci., 8(4):1325-2334.

Miao, L., Zhang, Y., Yang, X., Xiao, J., Zhang, H., Zhang, Z. and Jiang, G. 2016. Colored light-quality selective plastic films affect anthocyanin content, enzyme activities, and the expression of flavonoid genes in strawberry (Fragaria $\times$ ananassa) fruit. Food Chem., 207:93-100.

Neto, F. J.D., Tecchio, M. A., Junior, A. P., Bruna Thais Ferracioli Vedoato, B. T. F.,Lima, G. P. P., Roberto, S. R., 2017. Effect of ABA on colour of berries, anthocyanin accumulation and total phenolic compounds of 'Rubi' table grape (Vitis vinifera L.). AJCS 11(02):199-205.

Olivares D., Contreras, C., Munoz, V., Rivera, S., GonzalezAgüero, M., Retamales, J. and Defilippi, B. G. 2017. Relationship among color development, anthocyanin and pigment-related gene expression in 'Crimson Seedless' grapes treated with abscisic acid and sucrose. Plant Physio. Biochem., 115: 286-297

Omran, Y.A.M.M. 2011. Enhanced yield and fruit quality of Redglobe grapevines by abscisic acid (ABA) and Ethanol applications. J. Int. Sci. Vigne Vin.,45(1):1318.

Peppi, M.C. (2004). Color Development Studies in Table Grapes. M.S. Thesis, University of California, Davis, CA, USA. 84 pp

Peppi, M.C. and Fidelibus, M.W. 2008. Effects of forchlorfenuron and abscisic acid on the quality of 'Flame Seedless' grapes. HortScience, 43:173-176

Peppi, M.C., Fidelibus, M.W. and Dokoozlian, N. 2006. Abscisic acid application timing and concentration affect firmness, pigmentation, and color of 'Flame Seedless' grapes. HortScience, 41:1440-1445.

Peppi, M.C., Fidelibus, M.W. and Dokoozlian, N. 2007a. Application timing and concentration of abscisic acid affect the quality of 'Redglobe' grapes. J. Hortic. Sci. Biotech., 82:304-310.

Peppi, M.C., Fidelibus, M.W. and Dokoozlian, N. 2007b. Timing and concentration of abscisic acid affect the quality of ‘Crimson Seedless' grapes. Int. J. Fruit Sci., 7:71-83

Peppi, M.C., Walker, M.A. and Fidelibus, M.W. 2008. Application of abscisic acid rapidly upregulated UFGT gene expression and improved color of grape berries. Vitis , 47:11-14.
Roberto, S.R., De Assis, A.M., Yamamoto, L.Y., Miotto, L.C.V., Koyama, R. and Sato, A.J. and Borges, R.S. 2013 Ethephon use and application timing of abscisic acid for improving color of 'Rubi' table grape. Pesqui. Agropecu. Bras., 48:797-800.

Scavroni, J; L. C. Ferreira, M. L. L. Ferrarese, E. O. Ono, J. D. Rodrigues, 2018. Ethephon and calcium chloride, a combination that improves skin color of 'Rubi' table grape. Rev. Bras. Frutic., Jaboticabal, v. 40, n. 1: (e777): 1-10.

Shahab, M., Roberto, S. R., Ahmed, S., Colombo, R. C., Silvestre, J. P., Koyama, R. and Souza, R. T. 2019. Anthocyanin accumulation and color development of 'Benitaka' table application subjected to exogenous abscisic acid application at different timings of ripening. Agronomy 9, 164:1-12.

Spayd, S.E.,Tarara, J.M., Mee, D.L. and Ferguson, J.C. 2002. Separation of sunlight and temperature effects on the composition of Vitis vinifera cv. Merlot berries. Amer. J. Enol. Vitic.., 53:171-182.

Strydom, J. 2014. The effect of foliar potassium and seaweed products in combination with a leonardite fertigation product on Flame seedless grape quality. S. Afr. J. Enol. Vitic., 35(2): 283-291.

Sudha, G. and Ravishankar, G.A. 2003. Elicitation of anthocyanin production in callus cultures of Daucus carota and involvemente of calcium channel modulators. Current Science, Bangalore, 84: 775-779.

Szyjewicz, E., Rosner, N. and Kliewer, M.W. 1984. Ethephon ((2-Chloroethyl) phosphonic acid, Ethrel, CEPA) in viticulture - A review. Am. J. Enol. Vitic. 35:117-123.

Tomana, T., Utsonomiy, N. and Kataoka, L. 1979. The effect of environmental temperatures on fruit ripening on the tree. II. The effect of temperatures around whole vines and clusters on coloration of Kyoho grapes. J. Jap. Soc. Horti. Sci., 48:261-266.

Villegas, D., Handford, M., Alcalde, J. A. and Perez-Donoso, A. 2016. Exogenous application of pectin-derived oligosaccharides to grape berries modifies anthocyanin accumulation, composition and gene expression. Plant Physiol. Biochem. 104:125-133.

Williams, C.M.J., Maier, N.A. and Bartlett, L. 2004. Effect of molybdenum foliar sprays on yield, berry size, seed formation and petiolar nutrient composition of 'Merlot' grapevines. J. Plant Nutrition 27:1891-1916. Yamamoto, L.Y., Koyama, R., De Assis, A.M., Borges, W.F.S., De Oliveira, I.R. and Roberto, S.R. 2015. Color of berry and juice of 'Isabel' grape treated with abscisic acid in different ripening stages. Pesqui. Agropecu. Bras. 50:1160-1167.

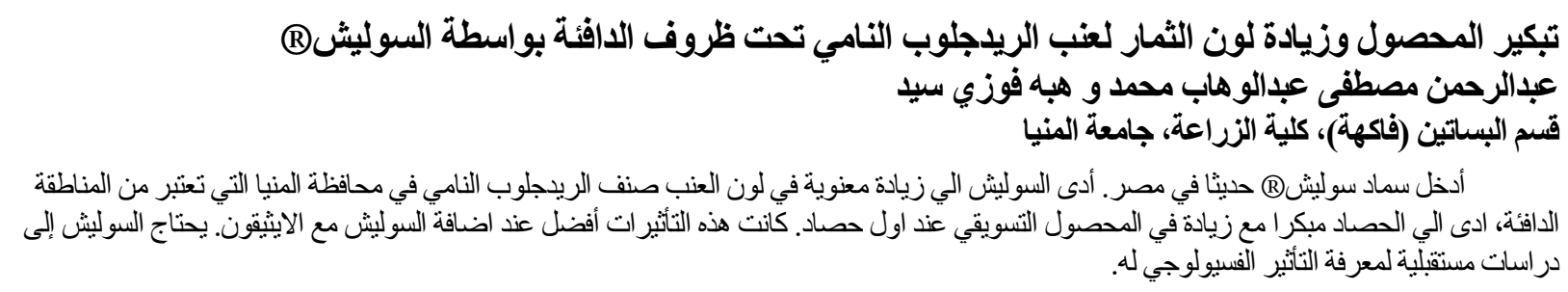

